\author{
GRZEGORZ HESS \\ Zakład Neurofizjologii i Chronobiologii \\ Instytut Zoologii i Badań Biomedycznych \\ Uniwersytet Jagiellonski $w$ Krakowie \\ Gronostajowa 9, 30-387 Kraków \\ E-mail: grzegorz.hess@uj.edu.pl
}

\title{
NIEDOBÓR SNU A NEUROPLASTYCZNOŚĆ
}

\section{WSTEP}

Sen jest szczególnym stanem behawioralnym, którego podstawowe przejawy to: leżaca pozycja ciała, ograniczona do minimum aktywność ruchowa i podniesiony próg wrażliwości na bodźce. Jednocześnie, aktywność bioelektryczna mózgu w trakcie snu pozostaje na wysokim poziomie, wykazując szereg charakterystycznych wzorców, na podstawie których rozróżnia się fazy snu REM i NREM oraz dzieli się fazę NREM na stadia (PACE-SCHOTT i HOBSON 2013). Fizjologia snu i jego rola sa od wielu lat przedmiotem intensywnych badań, które wskazuja na jego charakter anaboliczny, pozwalajacy organizmowi na zaoszczędzenie energii i służący regeneracji. Badania na zwierzętach wykazały, że długotrwały brak snu skutkuje śmiercia w rezultacie poważnych zaburzeń metabolizmu oraz czynności układu odpornościowego. Jednak w kontekście czynności mózgu wydaje się szczególnie interesujace, iż sen jest niezbędny dla prawidłowego przebiegu procesów leżących u podłoża zapamiętywania i tworzenia śladów pamiecciowych, a jego deficyt zaburza te procesy (PACE-SCHOTT i HoBson 2013). Jeden $z$ dwóch głównych, aktualnych nurtów badawczych, dotyczacych znaczenia snu dla utrwalania śladów pamięciowych, przypisuje mu funkcje polegajace na przywracaniu równowagi procesów komórkowych, zwiazanych $z$ zapamiętywaniem, a także odbudowie zasobów energetycznych i usuwaniu zbędnych produktów przemiany materii $z$ tkanki nerwowej, a więc kładzie nacisk na jego funkcję homeostatyczną. Drugi nurt badań koncentruje się na wy- soce swoistym przetwarzaniu informacji w trakcie snu, a szczególnie na jego znaczeniu dla procesów konsolidacji śladów pamięciowych (ACSADY i HARRIS 2017).

\section{HIPOTEZA HOMEOSTAZY SYNAPTYCZNEJ}

Aktywność sieci neuronalnych w trakcie czuwania, związana $z$ odbieraniem bodźców ze środowiska, ich przetwarzaniem oraz sterowaniem reakcjami behawioralnymi na nie, prowadzi w rozległych obszarach mózgu do wzmacniania połaczeń synaptycznych pomiędzy neuronami, dzięki plastyczności synaptycznej, której mechanizm na poziomie komórkowym działa zgodnie $z$ reguła $\mathrm{Heb}-$ ba (KossuT 2018). Plastyczność tego rodzaju jest związana w głównej mierze $z$ długotrwałym wzmocnieniem synaptycznym (ang. long-term potentiation, LTP) - utrzymującym się przez dłuższy czas (in vitro - godziny, in vivo - tygodnie) nasileniem wagi (wydajności) połączeń synaptycznych, wywołanym odpowiednim, krótkotrwałym, lecz intensywnym pobudzeniem synapsy (BYRNE 2013). Hipoteza homeostazy synaptycznej (TONONI i CIRELLI 2003) zakłada, że przetwarzanie informacji w rozległych sieciach neuronalnych w trakcie czuwania, rozumianego jako stan przeciwny do snu, skutkuje ogólnym wzmocnieniem pobudzających połączeń synaptycznych w mózgu, a szczególnie w korze mózgowej. W trakcie snu dochodziłoby natomiast do osłabienia tych połączeń. Ponieważ wystąpienie zmiany plastycznej w synapsie jednocześnie limituje możliwość powstania dalszych zmian w tym samym kierunku, gdyż zakres

Słowa kluczowe: konsolidacja śladu pamięciowego, plastyczność homeostatyczna, plastyczność synaptyczna, sen NREM, sen REM 
modyfikacji synapsy jest ograniczony; osłabienie takie pozwalałoby na wykorzystanie możliwości plastycznych synapsy w kodowaniu informacji w dłuższym okresie. Oprócz tego, ogólne osłabienie połączeń synaptycznych ograniczałoby zużycie energii przez komórki nerwowe i nie pozwalałoby na nadmierny rozrost synaps, do którego dochodzi wraz ich wzmocnieniem. Zgodnie $z$ hipoteza homeostazy synaptycznej, ogólna waga połączeń pobudzających $\mathrm{w}$ mózgu osiagałaby maksimum tuż przed zaśnięciem, natomiast w trakcie snu zachodziłoby stopniowe jej obniżenie, prowadzące do „resetu” możliwości plastycznych synaps. Istnieja mocne dane doświadczalne, potwierdzające tę hipotezę. Wykazano, że wielkość sygnału bioelektrycznego, rejestrowanego w korze mózgowej szczura w odpowiedzi na bodźce elektryczne i będącego miara aktywności glutaminianergicznych synaps pobudzajacych, ulega powiększeniu w miarę przedłużania czasu aktywności badanych zwierzat. Natomiast wielkość tego sygnału zmniejsza się $\mathrm{w}$ miarę trwania snu NREM, w czasie którego neurony kory mózgowej wykazuja aktywność synchroniczna w zakresie $0,5-2 \mathrm{~Hz}$ (rytm delta; VYAZOVSKIY i współaut. 2008).

Wzmocnienie pobudzajacych połączeń synaptycznych w mózgu, tak jak i jego model doświadczalny LTP, opiera się na zależnych od aktywności neuronalnej i synaptycznej mechanizmach komórkowych, które sa uruchamiane przede wszystkim w efekcie aktywacji jednego $\mathrm{z}$ rodzajów jonotropowych receptorów dla glutaminianu, receptorów kwasu N-metylo-D-asparaginowego (NMDA), zlokalizowanych na powierzchni neuronu postsynaptycznego (BYRNE 2013). Receptory te, będące jednocześnie błonowymi kanałami jonowymi, w stanie aktywnym przepuszczaja do wnętrza komórki jony $\mathrm{Ca}^{2+}$. Uruchamia to szereg wewnatrzkomórkowych procesów biochemicznych, zależnych od stężenia jonów $\mathrm{Ca}^{2+}$, prowadzacych do wzrostu wagi synapsy. Wzmocnienie przekaźnictwa synaptycznego najczęściej wiąże się ze zwiększeniem liczby jonotropowych receptorów dla kwasu a-amino-3-hydroksy-5-metylo4-izoksazolopropionowego (AMPA) w błonie postsynaptycznej na skutek ich eksternalizacji, do czego dochodzi już w krótkim czasie po aktywacji synapsy. Receptory AMPA odpowiadaja za powstawanie pobudzajacych prąów postsynaptycznych, stanowiacych podstawę przekazywania sygnału w synapsie glutaminianergicznej. Następnie, w efekcie aktywacji procesów ekspresji genów dochodzi do przebudowy struktury kolców dendrytycznych, niewielkich wypustek dendrytów, tworzacych elementy postsynaptyczne synaps pobudzających. Tego typu zjawiska plastyczności cechuje swoistość, czyli występowanie jedynie $\mathrm{w}$ tych połączeniach synaptycznych, spośród tysięcy znajdujących się na pojedynczych komórkach nerwowych kory mózgowej, które wykazywały intensywną aktywność w określonej sytuacji (kontekście). Z drugiej strony, postulowane zmiany homeostatyczne, zachodzace $\mathrm{w}$ trakcie snu, maja charakter nieswoisty i dotycza w równej mierze wszystkich synaps, niezależnie od ich stanu wyjściowego (TONONI i CIRELLI 2003).

Późniejsze badania wykazały, że zwiazane ze snem NREM homeostatyczne zmiany synaptyczne moga występować również w korze mózgowej człowieka (KUHN i współaut. 2016), jednak nie maja charakteru uniwersalnego, gdyż u szczurów stwierdzono ich występowanie w korze czuciowej i ruchowej, lecz nie w korze wzrokowej (NIETHARD i BORN 2019). Na poziomie molekularnym, za uruchomienie homeostatycznego, nieswoistego mechanizmu osłabienia wydajności połaczeń synaptycznych odpowiadaja postsynaptyczne receptory glutaminianu mGluR5, będace receptorami metabotropowymi, które $\mathrm{w}$ kolcach dendrytycznych zlokalizowane sa w strefie okołosynaptycznej. Aktywacja receptora mGluR5 przez czasteczki glutaminianu uruchamia, za pośrednictwem sprzężonego $\mathrm{z}$ receptorem białka $G_{q}$, wewnątrzkomórkowe szlaki sygnalizacyjne ${ }^{\prime}$ wiazane $z$ produkcja inozytolo-3 fosforanu (IP3) i diacyloglicerolu (DAG). Funkcje te receptor mGluR5 pełni w trakcie czuwania, pozostajac $\mathrm{w}$ interakcji $\mathrm{z}$ cząsteczkami białek cytoplazmatycznych z grupy Homer, a za ich pośrednictwem $-z$ wewnatrzkomórkowym receptorem IP3. W trakcie snu do wnętrza kolców dendrytycznych dociera skrócona izoforma białka Homer (Homer-1a), która w kompleksach $z$ receptorem mGluR5 zastępuje izoformy białka Homer o pełnej długości. Efektem tej zamiany jest odłaczenie receptora mGluR5 od białek efektorowych (DIERING i współaut. 2017). Aktywność receptora mGluR5 w kompleksie z białkiem Homer-1a prowadzi do usuwania z błony postsynaptycznej kolców dendrytycznych części znajdujących się tam receptorów AMPA na drodze internalizacji (CINGOLANI i współaut. 2019), co jest równoznaczne $z$ osłabieniem wagi synapsy. Jest interesujace, że po połaczeniu $\mathrm{z}$ białkiem Homer-1a receptor mGluR5 wykazuje aktywność konstytutywna, co oznacza, że nie wymaga do swojej aktywności obecności agonisty - czasteczki glutaminianu (Cingolani i współaut. 2019). Tłumaczy to, dlaczego usuwanie błonowych receptorów AMPA i obniżenie wagi synaptycznej $\mathrm{w}$ tych warunkach ma charakter nieswoisty i niezależny od aktywności neuronalnej. 
$\mathrm{Na}$ podstawie hipotezy homeostazy synaptycznej można zinterpretować wyniki badań wskazujących np., że pozbawienie snu przez 72 godz. blokuje możliwość wywołania LTP w hipokampie szczura (MCDERMOTT i współaut. 2003). Wykazano również niedawno, iż deficyt snu wynoszący 5 godz. powoduje podwyższenie gęstości niektórych kolców dendrytycznych i ich zwiększona objętość w neuronach hipokampa myszy, co świadczy o wzmocnieniu synaps (GISABELLA i współaut. 2020), choć należy podkreślić, że istnieje szereg prac wskazujacych na efekty przeciwne (np. HAVEKES i ABEL 2017). Warto również zwrócić uwage że, teoretycznie, nieswoiste, ogólne obniżenie wagi synaptycznej o określony współczynnik nie zaburza relacji pomiędzy waga synapsy, w której zaszło wcześniej wzmocnienie, a pozostałymi synapsami. Jednak $z$ drugiej strony, hipoteza ta nie uwzględnia faktu, iż tworzenie śladu pamięciowego jest procesem złożonym i rozciagniętym w czasie.

\section{KONSOLIDACJA ŚLADU PAMIECIOWEGO}

Badania mechanizmów pamięci wykazały, iż można wyróżnić trzy etapy powstawania śladu pamięciowego: uczenie (się), przechowywanie nowo nabytej informacji w zasobach pamięci krótkotrwałej przez okres rzędu minut i godzin, oraz przechowywanie informacji w zasobach pamięci długotrwałej, które może trwać całe życie (DiEKELMANN i BORN 2010). Przechowywanie nowo nabytej informacji ma poczatkowo charakter nietrwały, a w przypadku pamięci epizodycznej jest uzależnione od hipokampa, struktury położonej w mózgu człowieka w obrębie płata skroniowego, posiadajaccej duże możliwości plastyczne, lecz o ograniczonej pojemności. $\mathrm{Na}$ tym etapie fragmenty śladu pamięciowego, stanowiące łącznie mózgową reprezentację określonego zdarzenia, sa rozproszone w postaci połaczonych ze soba grup neuronów w różnych obszarach mózgu, a rola hipokampa jest powiazanie tych składowych w całość. Jednak taka forma śladu pamięciowego jest mało stabilna. Uważa się, że do powstania trwałej reprezentacji danego epizodu niezbędne jest wystapienie procesu aktywnej konsolidacji systemowej (BORN i WILHELM 2012), polegajacej na wielokrotnej reaktywacji sieci połaczonych neuronów, stanowiącej ślad pamięciowy. Do tego rodzaju wielokrotnej reaktywacji dochodzi przy udziale hipokampa w trakcie snu. Procesy plastyczności synaptycznej, zachodzące w trakcie aktywnej konsolidacji systemowej, prowadza do reorganizacji pierwotnej reprezentacji danego zdarzenia w korze mózgowej, która obejmuje trwałe wzmocnienie niektórych połączeń synaptycznych, a także tworzenie nowych połączeń i osłabianie innych. W pełni skonsolidowany (utrwalony) ślad pamięciowy zlokalizowany jest $\mathrm{w}$ obwodach neuronalnych kory mózgowej i może być całkowicie niezależny od hipokampa. Jednak uważa się, że hipokamp może w dalszym ciagu zawierać informację „referencyjną" o śladach pamięciowych zlokalizowanych w korze nowej. Informacja taka byłaby reaktywowana $\mathrm{w}$ momencie przypominania o zdarzeniu, wraz $z$ reaktywacja trwałego śladu pamięciowego rezydujaccego $w$ korze (KLINZING i współaut. 2019).

$\mathrm{Na}$ znaczenie procesu konsolidacji śladu pamięciowego wskazuje np. doświadczenie $z$ zastosowaniem labiryntu wodnego Morrisa, w którym szczury pozbawione snu przez 6 godz. równie szybko, jak zwierzęta kontrolne, uczyły się, gdzie pod powierzchnia wody znajduje się platforma, na która można się wspiąć, aby uniknąc konieczności pływania. Jednak $\mathrm{w}$ przeciwieństwie do zwierząt kontrolnych, szczury $z$ deficytem snu nie potrafiły odnaleźć platformy w 24 godz. później (GUAN i współpr. 2004).

Decydująca rolę hipokampa w konsolidacji śladu pamięciowego wiąże się ze szczególnym wzorcem aktywności elektrofizjologicznej neuronów tej struktury, nosząca w języku angielskim nazwę sharp wave ripple (SWR) (BUZSAKI 2015). W hipokampie, w warstwie dendrytów apikalnych (łac. stratum radiatum) neuronów piramidowych pola CA1, wyładowanie SWR ma postać pojedynczej fali o polaryzacji ujemnej (ang. sharp wave). Natomiast w warstwie perikarionów komórek piramidowych (łac. stratum pyramidale) hipokampa polaryzacja tej fali jest dodatnia, a nakłada sie na nia krótka seria oscylacji o częstotliwości sięgającej 140-250 $\mathrm{Hz}$ (ang. ripple). Czas trwania pojedynczego wyładowania SWR nie przekracza $100 \mathrm{~ms}$. Wykazano, że aktywność typu SWR zwiazana jest $z$ transferem informacji $z$ hipokampa do kory mózgowej, a także do takich obszarów podkorowych, jak brzuszne prażkowie (ATHERTON i współaut. 2015).

$\mathrm{Na}$ rolę aktywności SWR w konsolidacji śladów pamięciowych zwraca uwage fakt, iż pojawia się ona $\mathrm{w}$ hipokampie gryzoni $\mathrm{w}$ czasie, gdy zwierzęta pozostaja w bezruchu lub śpia, po wykonaniu zadania polegajacego na przebyciu określonej trasy (GIRARDEAU i ZUGARO 2011). W trakcie poruszania się zwierzęcia po poznanej wcześniej trasie, w miarę zmiany jego położenia, w hipokampie aktywuja się w określonej kolejności pojedyncze komórki nerwowe, określane jako komórki miejsca, które koduja lokalizację w danym momencie, co zwiazane jest $z$ fak- 
tem istnienia $\mathrm{w}$ hipokampie reprezentacji przestrzennej otoczenia (MOSER i współaut. 2015). W trakcie lokomocji, aktywność poszczególnych komórek miejsca nakłada się na charakterystyczny rytm aktywności hipokampa w zakresie 6-12 $\mathrm{Hz}$ (pasmo theta). Jest niezmiernie interesujace, że w fazie snu NREM, w trakcie wyładowań SWR dochodzi do odtworzenia (ang. replay) aktywności tych komórek miejsca, które wykazywały aktywność w czasie lokomocji i to w tej samej, określonej kolejności. Odtworzenie tej sekwencji zachodzi jednak dwudziestopięciokrotnie szybciej (GIRARDEAU i ZUGARO 2011, POULTER i współaut. 2018). Wykazano, że selektywna blokada wyładowań SWR w hipokampie utrudnia zdolności szczurów do nauczenia się wykonania zadania $w$ teście labiryntu radialnego $\mathrm{w}$ okresie $15 \mathrm{dni}$, co dowodzi decydującego znaczenia aktywności SWR w procesach konsolidacji pamięci przestrzennej (TODOROVA i ZUGARO 2020).

Hipokampalne wyładowania SWR moga pobudzać neurony w rozległych obszarach kory mózgowej. Jednak dla konsolidacji śladu pamięciowego, oprócz aktywności SWR w hipokampie, decydujace znaczenie ma występowanie w korze mózgowej, charakterystycznej dla snu NREM bioelektrycznej aktywności wolnofalowej (fale delta), a także tzw. wrzecion snu (TODOROVA i ZugARO 2020). Te ostatnie sa trwajacymi od 0,5 do 2 s oscylacjami, w mózgu ludzkim występującymi w zakresie częstotliwości $10-15 \mathrm{~Hz}$, o amplitudzie stopniowo narastajacej, a następnie malejacej, wywoływanymi w korze mózgowej przez połaczenia pochodzace $z$ jądra siatkowatego wzgórza. Badania na szczurach wykazały, że zdolności tych zwierzat do zapamiętania położenia obiektów i ich rozpoznawania ulegały znacznemu polepszeniu, jeżeli przy pomocy odpowiednio skierowanej stymulacji elektrycznej doprowadzano do wywołania w korze mózgowej fal delta i następujących po nich wrzecion w momencie wystapienia wyładowań SWR w hipokampie (MAINGRET i współpr. 2016). Równocześnie występująca aktywność wolnofalowa i wrzeciona tworza w korze mózgowej warunki, w których ułatwione jest zachodzenie procesów plastycznych (KLINZING i współpr. 2019). Doświadczenia te wskazuja, że dla konsolidacji śladów pamięciowych decydujace znaczenie ma nie tylko występowanie określonych wzorców aktywności elektrofizjologicznej w hipokampie i korze mózgowej, lecz przede wszystkim ich koincydencja, co pozostaje w zgodzie $z$ wcześniejszymi modelami teoretycznymi (DIEKELMANN i BORN 2010).

Omówione wyniki koncentruja się na roli snu NREM w pamięci, lecz nie uwzględniaja fazy snu REM. Nowsze badania wykazały, że rola snu REM może polegać na uzupełnianiu procesów plastyczności synaptycznej, zachodzących na poziomie komórkowym we wcześniejszych epizodach snu NREM. Uważa się, że w trakcie czuwania dochodzi do wstępnego „oznaczania” aktywnych synaps przy pomocy odpowiednich znaczników molekularnych, a do finalnego wzmocnienia synaps, a zatem i konsolidacji śladu pamięciowego, dochodziłoby $w$ efekcie zmian funkcjonalnych i strukturalnych, wymagajacych procesów transkrypcji i translacji, które przebiegaja początkowo w trakcie snu NREM, a następnie REM (SEIBT i FRANK 2019).

Niedobór snu powoduje podniesienie poziomu adenozyny w środowisku międzykomórkowym, będace zjawiskiem stanowiącym wspólny efekt działania tzw. czynników snu (PORKKA-HEISKANEN i KalinchuK 2011). Wykazano, że adenozyna, działając za pośrednictwem swoistych receptorów A1, obniża aktywności cyklazy adenylanowej a w konsekwencji - hamuje zależną od czynnika CREB ekspresję genów na etapie transkrypcji oraz procesy translacji zachodzace przy udziale ścieżki sygnalizacyjnej mTOR, a także aktywność ścieżki sygnałowej PKA (kinaza białkowa A) - kinaza LIM - kofilina, związanej $z$ regulowaniem morfologii kolców dendrytycznych (HAVEKES i ABEL 2017). Prawidłowa aktywność tych szlaków ma zasadnicze znaczenie dla długotrwałych modyfikacji wydajności przekaźnictwa synaptycznego.

\section{PODSUMOWANIE}

Badania ostatnich lat wykazały, jak istotne znaczenie dla tworzenia śladów pamięciowych w mózgu ma sen. Choć badania te, inspirowane hipotezami homeostazy synaptycznej i aktywnej konsolidacji systemowej, prowadzone były w różnych kierunkach, to wydaje się, że uzyskane wyniki nie sa sprzeczne, lecz przeciwnie, uzupełniaja się, ponieważ występowanie wysoce swoistych zmian wzrostu wagi synaptycznej w określonych obwodach neuronalnych, w których zachodzi aktywna konsolidacja systemowa, nie wyklucza równoczesnych zmian homeostatycznych zwiazanych $z$ osłabieniem przekaźnictwa synaptycznego w pozostałych, wielokrotnie liczniejszych synapsach w mózgu. Co więcej, obydwa procesy moga zachodzić równocześnie na poziomie pojedynczych neuronów. Obserwacje, wskazujace, że brak snu zaburza zdolności do zapamiętywania, można uzasadnić na podstawie obydwu hipotez, jednak dopiero przyszłe badania pokaża, jaka jest rola snu w utrwalaniu śladów $z$ zakresu pamięci deklaratywnej i proceduralnej w różnych obszarach mózgu, 
a także, jak zaburzenia architektury snu, występujące np. u osób w wieku podeszłym, wpływaja na zapamiętywanie.

\section{Streszczenie}

Niedobór snu wywiera negatywny wplyw na funkcje poznawcze mózgu, w tym zdolności do uczenia się i zapamiętywania. Szereg danych doświadczalnych wskazuje, iż sen ma zasadnicze znaczenie dla utrzymania homeostazy mózgu i konsolidacji śladów pamięciowych. Obydwa zjawiska opieraja się w dużej mierze na procesach plastyczności synaptycznej, uzależnionej od zwiazanych ze snem wzorców aktywności bioelektrycznej mózgu. Niniejszy artykuł koncentruje się na dwóch hipotezach, które zdominowały badania nad funkcja i znaczeniem snu w ostatnich latach: hipoteza homeostazy synaptycznej i hipoteza aktywnej konsolidacji systemowej oraz przytacza dane uzyskane $z$ badań na modelach zwierzęcych, wykazujacych, jak deficyt snu wplywa na leżące u podstaw tych zjawisk, mechanizmy plastyczności synaptycznej.

\section{LITERATURA}

ACSADY L., HARRIS K. D., 2017. Synaptic scaling in sleep. Science 355, 457.

Atherton L. A., Dupret D., Mellor J. R., 2015. Memory trace replay: The shaping of memory consolidation by neuromodulation. TINS 38, 560-570.

BORN J., WILHELM I., 2012. System consolidation of memory during sleep. Psychol. Res. 76, 192-203.

BUZSAKI G., 2015. Hippocampal sharp wave-ripple: A cognitive biomarker for episodic memory and planning. Hippocampus 25,1073-1188.

BYRNE J. H., 2013. Learning and Memory: Basic Mechanisms. [W:] Fundamental Neuroscience. SQUIRE L. R. i współaut. (red.). Academic Press, Cambridge, Massachusetts, 1009-1027.

Cingolani L.A., Vitale C., DityateV A., 2019. Intra- and extracellular pillars of a unifying framework for homeostatic plasticity: a crosstalk between metabotropic receptors and extracellular matrix. Front. Cell. Neurosci. 13, 513.

DIEKELMANN S., BORN J., 2010. The memory function of sleep. Nat. Rev. Neurosci. 11, 114126.

Diering G. H., Nirujogi R. S., Roth R. H., WoRLEY P. F., PANDEY A., HUGanir R. L., 2017. Homerla drives homeostatic scaling-down of excitatory synapses during sleep. Science 355, 511-515.

GirardeAU G., Zugaro M., 2011. Hippocampal ripples and memory consolidation. Curr. Opin Neurobiol. 21, 452-459.

Gisabella B., Scammel T., Bandaru S. S., SAPER C. B., 2020. Regulation of hippocampal den- dritic spines following sleep deprivation. J. Comp. Neurol. 528, 380-388.

GUAN Z., PENG X., FANG J., 2004. Sleep deprivation impairs spatial memory and decreases extracellular signal-regulated kinase phosphorylation in the hippocampus. Brain Res. 1018, 38-47.

HAVEKES R., ABel T., 2017. The tired hippocampus: The molecular impact of sleep deprivation on hippocampal function. Curr. Opin. Neurobiol. 44, 13-19.

KLINZING J. G., NIETHARD N., BORN J., 2019. Mechanisms of systems memory consolidation during sleep. Nat. Neurosci. 22, 1598-1610.

KossuT M., 2018. Neuroplastyczność. Wydawnictwo Medyk, Łomianki.

Kuhn M., Wolf E., Maier J. G., Mainberger F., FEIGE B. i współaut. 2016. Sleep recalibrates homeostatic and associative synaptic plasticity in the human cortex. Nat. Commun. 7, 12455.

MaingRet N., Girardeau G., TODOROVA R., GoutIERRE M., ZugARO M., 2016. Hippocampo-cortical coupling mediates memory consolidation during sleep. Nat. Neurosci. 19, 959-964.

McDermott C. M., Lahoste G. J., Chen C., Musto A., Bazan N. G., Magee J. C., 2003. Sleep deprivation causes behavioral, synaptic, and membrane excitability alterations in hippocampal neurons. J. Neurosci. 23, 9687-9695.

Moser M. B, Rowland D. C., Moser E. I., 2015. Place cells, grid cells and memory. Cold Spring Harb. Perspect. Biol. 7, a021808.

NIETHARD N., BORN J., 2019. Back to baseline: sleep recalibrates synapses. Nat. Neurosci. $22,149-151$.

PACE-SchotT E. F., Hobson J. A., 2013. The neurobiology of sleep and dreaming. [W:] Fundamental Neuroscience. SoUIRE L.R. i współaut. (red.). Academic Press, Cambridge, Massachusetts, 847-869.

PorkKa-Heiskanen T., KalinchuK A. V., 2011. Adenosine, energy metabolism and sleep homeostasis. Sleep Med. Rev. 15, 123-135

Poulter S., HARTley T., LeVer C., 2018. The neurobiology of mammalian navigation. Curr. Biol. 28, R1023-R1042.

SEIBT J., FRANK M. G., 2019. Primed to sleep: The dynamics of synaptic plasticity across brain states. Front. Syst. Neurosci. 13, 2.

TODOROVA R., Zugaro M., 2020. Hippocampal ripples as a mode of communication with cortical and subcortical areas. Hippocampus 30, 3949.

Tononi G., Cirelli C., 2003. Sleep and Synaptic Homeostasis: A Hypothesis. Brain Res. Bull. 62, 143-150.

Vyazovskiy V. V., Cirelli C., Pfister-Genskow M., FARAguna U., TONONI G. 2008. Molecular and electrophysiological evidence for net synaptic potentiation in wake and depression in sleep. Nat. Neurosci. 11, 200-208. 
KOSMOS Vol. 69, 3, 441-446, 2020

\section{GRZEGORZ HESS}

Department of Neurophysiology and Chronobiology, Institute of Zoology and Biomedical Research, Jagiellonian University in Kraków, 9 Gronostajowa Str., 30-387 Kraków,E-mail: grzegorz.hess@uj.edu.pl

\section{SLEEP DEFICIT AND NEUROPLASTICITY}

Sleep deprivation has a negative impact on the cognitive functions of the brain, including learning and memory. A number of experimental data indicate that sleep is essential for maintaining brain homeostasis and consolidating memory traces. Both phenomena are largely based on processes of synaptic plasticity, dependent on sleep-related patterns of the brain's bioelectric activity. This article focuses on two hypotheses that have dominated research on sleep function and significance in recent years, the hypothesis of synaptic homeostasis and the hypothesis of active systemic consolidation, and cites data from animal model studies showing how sleep deprivation affects the underlying effects of sleep phenomena, mechanisms of synaptic plasticity.

Key words: homeostatic plasticity, memory consolidation, NREM sleep, REM sleep, synaptic plasticity 